\title{
IAMJ
}

INTERNATIONAL

AYURVEDIC

MEDICAL JOURNAL

\section{HEALTH STATUS OF GERIATRIC POPULATION IN RURAL AND URBAN AREAS OF VARANASI - A COMPARATIVE STUDY}

\section{Gupta Yogesh Chandra ${ }^{1}$, Nathani Neeru ${ }^{2}$}

${ }^{1}$ Research Scholar, Department of Swasthavritta and Yoga, Faculty of Ayurveda, Institute of Medical Sciences, Banaras Hindu University, Varanasi, Uttar Pradesh, India.

${ }^{2}$ Professor and Head, Department of Swasthavritta and Yoga, Faculty of Ayurveda, Institute of Medical Sciences, Banaras Hindu University, Varanasi, Uttar Pradesh, India

\section{Corresponding Author: nsneeru@yahoo.co.in}

https://doi.org/10.46607/iamj2509022021

(Published online: February 2021)

Open Access

(C) International Ayurvedic Medical Journal, India 2021

Article Received:31/01/2021 - Peer Reviewed:06/02/2021 - Accepted for Publication:08/02/2021

Check for updates

\section{ABSTRACT}

The purpose of this study was to assess the health-related problems of rural and urban geriatric population of Varanasi district. A survey-based cross-sectional study was carried out on total 1000 elderly of selected rural and urban areas of Varanasi district by multistage random sampling. Health related details of the respondents were gathered through an interview schedule. Most of the respondents were in the age group of 60 to 69 years. The prevalence of hypertension, heart diseases, respiratory diseases, and urinary diseases were significantly higher in rural areas than in urban areas, whereas the prevalence of diabetes mellitus, musculoskeletal problems, and gastrointestinal diseases were significantly higher in urban areas. This study revealed a significant variation in the health status of rural and urban elderly of Varanasi district. People need to be aware of old age and elderly to pay proper attention for better health care to make this later stage of life more pleasant and healthy.

Keywords: Geriatric, Health, Rural, Urban. 


\section{INTRODUCTION}

In last few decades, due to development, research, inventions and new techniques in medical field worldwide, the age expectancy of people has steadily improved. As a result the proportion of older people in world's population is increasing rapidly. ${ }^{1}$ By 2050 , the global population of 60 and older is presumed to reach approximately two billion, with the proportion of older people doubling within 2006 and $2050 .^{2}$ The elderly population in India is increasing with both share and size over time. The percentage of the total elderly population was increased from $5.6 \%$ in 1961 to $8.6 \%$ in 2011. It was marginally lower at $8.2 \%$ for males, while it was $9.0 \%$ for females.

Aging is a biological phenomenon that occurs in the life of every organism. The method of aging in a human being is estimated by comparing the biological age and chronological age. Aging is identified as the stage of physical deterioration. At this period, the nervous system gets relaxed and Cataract or glaucoma develops in the eyes. ${ }^{3}$ If timely and suitable remedy is not available, they have lot of problems in seeing and recognizing people and other things. At this stage of life, the growth of the cells of the body declines. Cells, tissues, and organs undergo a myriad of changes with aging. This diminishes or eliminates the capability to fight against diseases. There is no dispute on the view that much age-related pathology is common with old age. ${ }^{4}$ A report of World Health Organization states that non-communicable diseases account for at least $32 \%$ of all deaths in India with a word of caution that this could be under an inadequate estimation. ${ }^{5}$

Aim and Objective: In North India the studies on health problems of elderly are very few. Comparative studies on the health status of rural and urban elderly in Varanasi are also lacking. This study has been carried out to overcome this gap of old age studies and to understand the health problems of elderly in two different environments. The objective of this study was to compare the health status of elderly in rural and urban areas of Varanasi district.

\section{Materials and Methods:}

This cross-sectional study was conducted on elderly aged 60 years and above, selected from rural and urban areas of Varanasi district, by multistage stratified random sampling. A sample size of 1000 was calculated using the formula $Z^{2} x p(1-p) / d^{2}$ based on the results obtained in the pilot study. Out of total eight blocks of Varanasi district, two blocks i.e. Arajilines and Cholapur were selected and 8 Gram Panchayats were selected from each of these two blocks. On the other hand, in urban areas out of total 90 wards the six wards were selected for this study.

All data for this study were collected from the period of January 2018 to September 2019. An interview schedule was prepared by the Research Scholar for the preliminary data. First section of the interview schedule was covered by demographic details. In second section a self-prepared scale of 10 questions was used for General Physical Functional Ability (Dressing, Feeding, Grooming, Washing, Bowels, and Mobility) along with vision and hearing condition. The third section covered BMI level of respondents and possible geriatric diseases related questions. The data were analyzed using statistical software SPSS Version 16. 


\begin{tabular}{|c|c|c|c|c|c|c|c|c|}
\hline \multicolumn{9}{|l|}{ Results } \\
\hline \multirow[t]{2}{*}{ Variables } & \multirow[t]{2}{*}{ Category } & \multicolumn{2}{|l|}{ Rural } & \multicolumn{2}{|l|}{ Urban } & \multicolumn{2}{|c|}{ Total } & \multirow{2}{*}{$\begin{array}{l}\text { Test of signifi- } \\
\text { cance }\end{array}$} \\
\hline & & $\mathrm{n}=\mathbf{5 0 0}$ & $\%$ & $n=500$ & $\%$ & No. & $\%$ & \\
\hline \multirow[t]{3}{*}{ Age Group } & $60-69$ & 391 & 78.2 & 404 & 80.8 & 795 & 79.5 & \multirow{3}{*}{$\begin{array}{l}x^{2}=1.632 \\
p=0 . .442\end{array}$} \\
\hline & $70-79$ & 95 & 19.0 & 80 & 16.0 & 175 & 17.5 & \\
\hline & $\geq 80$ & 14 & 2.8 & 16 & 3.2 & 30 & 3.0 & \\
\hline \multirow[t]{2}{*}{ Gender } & Male & 270 & 54.0 & 189 & 37.8 & 459 & 45.9 & \multirow{2}{*}{$\begin{array}{l}\chi^{2}=26.422 \\
p=0.000\end{array}$} \\
\hline & Female & 230 & 46.0 & 311 & 54.1 & 541 & 54.1 & \\
\hline \multirow{5}{*}{$\begin{array}{l}\text { Socio- } \\
\text { economic } \\
\text { Class }\end{array}$} & Upper & 11 & 2.2 & 78 & 15.6 & 89 & 8.9 & \multirow{5}{*}{$\begin{array}{l}\chi^{2}=177.802 \\
\mathbf{p}=\mathbf{0 . 0 0 0}\end{array}$} \\
\hline & Upper middle & 23 & 4.6 & 43 & 8.6 & 66 & 6.6 & \\
\hline & Middle & 39 & 7.8 & 105 & 21.0 & 144 & 14.4 & \\
\hline & Lower middle & 103 & 20.6 & 145 & 29.0 & 248 & 24.8 & \\
\hline & Lower & 324 & 64.8 & 129 & 25.8 & 453 & 45.3 & \\
\hline
\end{tabular}

Table 1: Demographic Features of respondents according to residence.

Majority of total respondents of both areas (79.5\%) belonged to age group of 60 to 69 years followed by $17.5 \%$ of age group of 70 to 79 years. More than half $(54 \%)$ of the respondents in the rural area were male while about one third (37.8\%) were in males urban areas. The percentage of female respondents was lower in rural areas $(46 \%)$ compared to urban areas
(54\%). The socio-economic classification of households was based on the Prasad BG scale revised version 2019 in the study, which calculates monthly per capita income. In this $45.3 \%$ respondents belonged to lower class families, out of them $64.8 \%$ were found in the rural areas while about one-fourth $(25.8 \%)$ belonged to urban areas.

\begin{tabular}{|c|c|c|c|c|c|c|c|}
\hline \multirow[t]{2}{*}{ Category } & \multicolumn{2}{|c|}{ Rural } & \multicolumn{2}{|c|}{ Urban } & \multicolumn{2}{|c|}{ Total } & \multirow{2}{*}{$\begin{array}{l}\text { Test of sig- } \\
\text { nificance }\end{array}$} \\
\hline & No & $\%$ & No. & $\%$ & No. & $\%$ & \\
\hline Very Severe Under weight $(<16)$ & 36 & 7.2 & 16 & 3.2 & 52 & 5.2 & $x^{2}=109.240$ \\
\hline Severe Under weight (16.1-17) & 24 & 4.8 & 48 & 9.6 & 72 & 7.2 & $p=0.000$ \\
\hline Under weight (17.1-18.4) & 101 & 20.2 & 40 & 8.0 & 141 & 14.1 & \\
\hline Normal (18.5-25) & 302 & 60.4 & 270 & 54.0 & 572 & 57.2 & \\
\hline Over weight (25.1-30) & 32 & 6.4 & 66 & 13.2 & 98 & 9.8 & \\
\hline Obese Class I (30.1-35) & 3 & 0.6 & 60 & 12.0 & 63 & 6.3 & \\
\hline Obese Class II $(>35)$ & 2 & 0.4 & 0 & 0.0 & 2 & 0.2 & \\
\hline
\end{tabular}

Table 2: BMI status of respondents according to residence.

There were 36 respondents from the rural area whose BMI level was 16 or below, whereas in the urban areas only 16 people were found of this category. In the severely underweight category, only half of the respondents were in the rural area $(4.8 \%)$ compared to their urban counterparts $(9.6 \%)$. On the other hand,
$20.2 \%$ of respondents of rural areas were in underweight category and only $8 \%$ were found in the urban areas. Apart from this, in overweight category only $6.4 \%$ of the respondents were of rural areas while $13.2 \%$ were of urban areas. This variation was statistically highly significant. 


\begin{tabular}{|c|c|c|c|c|c|c|c|c|}
\hline \multirow[t]{2}{*}{ Category } & \multicolumn{2}{|c|}{ Rural } & \multicolumn{2}{|c|}{ Urban } & \multicolumn{2}{|c|}{ Total } & \multirow{2}{*}{\multicolumn{2}{|c|}{ Test of significance }} \\
\hline & \multicolumn{2}{|c|}{ No. } & No. & $\%$ & & $\%$ & & \\
\hline Poor & 91 & 18.2 & 41 & 8.2 & 132 & 13.2 & \multirow{3}{*}{$\begin{array}{l}x^{2} \quad= \\
\mathbf{p}=\mathbf{0 . 0 0 0}\end{array}$} & \multirow[t]{3}{*}{83.879} \\
\hline Average & 357 & 71.4 & 294 & 58.8 & 651 & 65.1 & & \\
\hline Good & 52 & 10.4 & 165 & 33.0 & 217 & 21.7 & & \\
\hline
\end{tabular}

Table 3: General physical functional ability of respondents according to residence.

To observe the General Physical Functional Ability (GPFA), the capacities of eyes, ears and daily life activities (Dressing, Feeding, Grooming, Washing, Bowels, and Mobility) were assessed. The respondent's' GPFA was divided into three categories (Good, Average, and Poor) based on the score from the scale.
The prevalence of poor GPFA among the elderly in rural areas was higher $(18.2 \%)$ than in urban areas $(8.2 \%)$, whereas the respondents with good GPFA in urban areas were more $(33 \%)$ than in rural areas $(10.4 \%)$. This difference between both regions was highly significant $(\mathrm{P}<0.000)$.

\begin{tabular}{|l|l|l|l|l|l|}
\hline \multirow{2}{*}{ Name of disease } & \multicolumn{2}{|l|}{ Rural $\mathbf{( n = 5 0 0 )}$} & \multicolumn{2}{l|}{ Urban $(\mathbf{n}=\mathbf{5 0 0})$} & \multirow{2}{*}{ Test of significance } \\
\cline { 2 - 5 } & No & $\mathbf{( \% )}$ & No & $\mathbf{( \% )}$ & \\
\hline Hypertension & 210 & 42.0 & 146 & 29.2 & $x^{2}=17.865 \mathbf{p}=\mathbf{0 . 0 0 0}$ \\
\hline Diabetes Mellitus & 15 & 3.0 & 68 & 13.6 & $x^{2}=36.907 \quad \mathbf{p}=\mathbf{0 . 0 0 0}$ \\
\hline Heart diseases & 24 & 4.8 & 8 & 1.6 & $x^{2}=8.264 \quad \mathbf{p}=\mathbf{0 . 0 0 4}$ \\
\hline Musculoskeletal problems & 152 & 30.4 & 256 & 51.2 & $x^{2}=44.780 \mathbf{p}=\mathbf{0 . 0 0 0}$ \\
\hline Respiratory diseases & 85 & 17.0 & 57 & 11.4 & $x^{2}=6.435 \quad \mathbf{p}=\mathbf{0 . 0 1 1}$ \\
\hline Urinary diseases & 16 & 3.2 & 8 & 1.6 & $x^{2}=2.732 \quad \mathbf{p}=0.098$ \\
\hline Gastrointestinal diseases & 41 & 8.2 & 73 & 14.6 & $x^{2}=10.138 \mathbf{p}=\mathbf{0 . 0 0 1}$ \\
\hline
\end{tabular}

Table 4: Geriatric diseases of respondents according to residence.

The prevalence of Hypertension (42\%), Heart diseases (4.8\%), Respiratory diseases (17\%), and Urinary diseases $(3.2 \%)$ was higher in geriatric population of rural areas than of urban areas, whereas Diabetes Mellitus $(13.6 \%)$, musculoskeletal problems $(51.2 \%)$, and Gastrointestinal diseases (14.6\%) were comparatively more prevalent in urban areas. This difference in the prevalence of morbidity between rural and urban respondents was mostly highly significant $(\mathrm{p}<0.05)$.

\section{DISCUSSION}

In this study, most of the responders of both areas belonged to the age group of 60-69. According to the census $2011^{6}$, most of the elderly in Varanasi district were from this age group, in many other studies 5,7 more than half of the elderly belonged to same age group, which confirms the results of this study. we found a higher proportion of female elderly than males, which is supported by a study in rural areas of Varanasi. $^{8}$

Most of the respondents in entire study belonged to the lower socioeconomic class, but two-thirds of the respondents $(64.8 \%)$ in the rural area related to lower economic class, which were more than two times greater to urban geriatric population $(25.8 \%)$. A similar result was found in a comparative study of Verma et al. ${ }^{5}$ This observation makes it obvious that poverty in rural areas is high, which directly affects the health status of elderly.

The prevalence of malnourishment (underweight, sever underweight and very sever underweight) among the elderly in rural areas was significantly higher (32.2\%) than urban areas $(20.8 \%)$, whereas the over nutrition (overweight and obese) was significantly higher among the urban elderly compare to rural elderly. Similarly, about $39 \%$ of the elderly were underweight in a study conducted by Tiwari et $\mathrm{al}^{9}$, in a 
rural area of Varanasi district. Nearly the same condition of BMI in respondents was found in a similar study in Allahabad. ${ }^{5}$

The decline in physical functional ability is natural with increasing age, but its deterioration is not the same in all individuals. Functional ability degradation in old age effectively affects various aspects of life. The efficiency of daily living activities is examined to measure functional capacity. ${ }^{10}$ In our study, the physical functional ability was average in more than half $(65.1 \%)$ of the total respondents, but the number of elderly with poor physical functional ability was higher in rural respondents (18.2\%) than in urban respondents $(8.2 \%)$. The proportion of elderly with good functional ability was significantly higher in urban areas than in rural areas, whereas Vaish et al study in Delhi region that found $25.7 \%$ of the elderly had a poor functional ability ${ }^{11}$.

In this study the prevalence of hypertension was found in $35.7 \%$ of the respondents, but its proportion was significantly higher among rural elderly (42\%) than in urban ones $(29.2 \%)$. It may be due to a high percentage of illiteracy, lack of health awareness and lack of elderly access to medical services and information. The prevalence of hypertension extremely high (81\%) in a study conducted by Tiwari et al (2010) in rural areas of Varanasi ${ }^{9}$, while Kumar et al (2015) a found $34.1 \%$ prevalence of Hypertension. A study of Allahabad district was less hypertension in rural areas $(27.5 \%)$ and comparatively more in urban areas $(39 \%)^{5}$

This research revealed a significantly higher percentage of diabetes mellitus in respondents of urban areas compared to rural areas. In 2007, research in a rural area of Varanasi confirmed only $0.27 \%$ elderly suffered from Diabetes Mellitus. ${ }^{9}$ In 2012, a study carried out in an urban area of Varanasi reported $10 \%$ cases of Diabetes Mellitus. ${ }^{12}$ A comparative study in Allahabad affirmed $6 \%$ and $23.5 \%$ prevalence of diabetes in rural and urban areas respectively. ${ }^{5}$

In present study, the problems of heart diseases were reported more in geriatric population of rural areas (1.6\%) than of urban areas (4.8\%). In a study conducted by Zare VR et al (2018) in Hyderabad, the prevalence of heart diseases in respondents of rural and urban areas were $6 \%$ and $4 \%$ of the respondents, respectively. ${ }^{13}$

Total $40.8 \%$ of the elderly in the study suffered from musculoskeletal problems, but it was high in urban elderly respondents as compared to rural ones. In a study conducted by Tiwari S et al, observed $53 \%$ of the rural respondents had complaint of these problems ${ }^{9}$ and in a study of Kumar D at al (2015) $56.5 \%$ of the elderly reported the same problem. ${ }^{8}$ however Verma $\mathrm{V}$ at al observed in their study that $54.5 \%$ and $41 \%$ elderly had musculoskeletal problems in rural and urban areas respectively. ${ }^{5}$

Respiratory diseases were significantly higher in rural elderly (16\%) than in urban elderly (11.6\%). In study rural areas of Nainital district total $13.4 \%{ }^{14}$; in a study of rural area Varanasi $11 \%{ }^{9}$ and in a study in Karnataka $^{15} 10.7 \%$ of elderly respondents had respiratory diseases.

Urinary diseases observed in only $2.6 \%$ of total study population, of which $3.2 \%$ were respondents in rural areas and $1.6 \%$ in urban areas. Verma $\mathrm{V}$ et al observed in their comparative study $11.5 \%$ and $12.5 \%$ of elderly respondents had Urinary diseases in rural and urban areas, respectively; ${ }^{5}$ on the other hand, a study conducted in Lucknow revealed that many elderly respondents suffered from Urinary diseases. ${ }^{7}$

The proportion of respondents suffering from gastrointestinal tract disorder was found higher in urban elderly $(14.6 \%)$ than in rural elderly $(8.2 \%)$. Various studies revealed that prevalence of GIT disorders was higher in elderly population. , $^{92,7,14}$ However Kumar et al observed only $2 \%$ rural elderly suffered from GIT disorders. ${ }^{8}$

\section{CONCLUSION}

The assessment of health status of rural and urban elderly of Varanasi district exposed significant disparities in demographic characteristics of respondents. They faced various pathological problems in their existing circumstances. Hypertension, heart disease, respiratory diseases, urinary disease, and malnourishment were comparably high in rural elderly. On the contrary, diabetes mellitus, musculoskeletal disorders, and 
gastrointestinal disorders were more common in urban elderly. Hence it is necessary to understand these problems with their possible solution in early stage. Along with the development of age-friendly medical facilities in both areas, people should be aware of forthcoming old age to maintain good health. This is the key to healthy and happy old age.

\section{REFERENCES}

1. Office CS, Implementation P. Situation Analysis Of The Elderly in India. 2011;(June).

2. UNDESA. World Economic and Social Survey 2007: Development in an Ageing World.; 2007. United Nation- 2008

3. Suryakantha A. Community Medicine with Recent Advances. Jaypee Brothers Medical Publishers (P) Ltd.; 2017. doi:10.5005/jp/books/12912

4. Hayflick L. Debates: The Not-So-Close Relationship Between Biological Aging and Age-Associated Pathologies in Humans. Journals Gerontol Ser A Biol Sci Med Sci. 2004;59(6):B547-B550. doi:10.1093/gerona/59.6.b547

5. Verma V, Prakash S, Parveen K, Shaikh S, Mishra N. A Comparative Study of Morbidity Pattern in Elderly of Rural and Urban Areas of Allahabad District, Uttar Pradesh, India. International Journal of Community Medicine and Public Health (ijcmph) Vol 3.; 2016. doi:10.18203/2394-6040.ijemph20161375

6. 2011 C. Varanasi (Varansi) District Population Census 2011-2020, Uttar Pradesh literacy sex ratio and density. https://www.census2011.co.in/census/district/568varanasi.html. Accessed February 6, 2020.

7. Srivastava MR, Sachan B, Gupta P, Bhardwaj P, Srivastava JP, Bisht A (2013). Morbidity Status and Its Social Determinants among Elderly Population of Lucknow District, India. Scholars Journal of Applied Medical Sciences (SJAMS) Vol 1.; 2013.

8. Kumar D, Kumari R, Shankar H (2015). Health Status and Health Seeking Behaviour of Rural Geriatric Population of Varanasi District, India. Int J Med Sci Public Heal. 2015;4(12):1711. doi:10.5455/ijmsph.2015.22052015353

9. Tiwari S, Sinha AK, Patwardhan K, Gehlot S, Gambhir IS, Mohapatra SC (2010). Prevalence of Health Problems Among Elderly: Indian J Prev Soc Med I. 2010;41(3):2-6.

10. Activity, functional capacity and well-being in ageing Finnish workers | Occupational Medicine | Oxford
Academic. https://academic.oup.com/occmed/article/57/2/85/1581 046. Accessed April 22, 2020.

11. Vaish K, Patra S, Chhabra P (2020). Functional disability among elderly: A community-based crosssectional study. J Fam Med Prim Care. 2020;9(1):253. doi:10.4103/jfmpc.jfmpc_728_19

12. Mishra SK, Ravi Shankar CM (2012). Social Support and Health Status of the Geriatric Population in Urban Varanasi. Indian J. Prev. Soc. Med. Vol. 43 No.4, 2012

13. Zare VR, Kokiwar P, Ramesh B (2018). Health Status of Elderly: A Comparative Study among Urban and Rural Dwellers. International Journal of Community Medicine and Public Health Zare VR et al. Int J Community Med Public Health. 2018 Jul;5(7):3039-3044 http://www.ijcmph.com

14. Bartwal J, Rawat CMS, Awasthi S (2016). Morbidity pattern among the geriatric population in rural area of Haldwani block in Nainital district of Uttarakhand. Indian J Forensic Community Med. 2016;3(3):209. doi:10.5958/2394-6776.2016.00046.1

15. Lena A, Ashok K, Padma M, Kamath V, Kamath A (2009). Health and Social Problems of the Elderly: A Cross-Sectional Study in Udupi Taluk, Karnataka. Indian Journal of Community Medicine / Vol. 34 / Issue 2 / April 2009.

\section{Source of Support: Nil Conflict of Interest: None Declared}

How to cite this URL: Gupta Yogesh Chandra \& Nathani Neeru: Health Status Of Geriatric Population In Rural And Urban Areas Of Varanasi - A Comparative Study. International Ayurvedic Medical Journal \{online\} 2021 \{cited February, 2021\} Available from: http://www.iamj.in/posts/images/upload/479 484.pdf 